\title{
МОДИФИЦИРОВАНИЕ ГАЛЬВАНИЧЕСКОГО ПОКРЫТИЯ ОЛОВО-ВИСМУТ УГЛЕРОДНЫМИ НАНОТРУБКАМИ ДЛЯ ПОВЫШЕНИЯ КОРРОЗИОННОЙ СТОЙКОСТИ
}

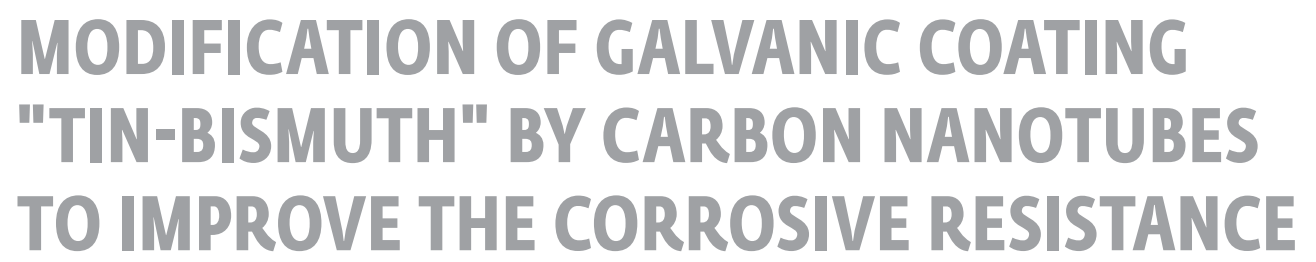

Д.В.Давыдова', (ORCID: 0000-0003-2221-5785), Н.В.Тарасова², кандидат технических наук, доцент, И.А.Дьяков', кандидат технических наук, доцент, Ю.В.Литовка', доктор технических наук, профессор (ORCID: 0000-0002-5792-340X) / upiakvk.tstu@gmail.com D.V.Davydova', (ORCID: 0000-0003-2221-5785), N.V.Tarasova², Candidate of Technical science, Docent, I.A.Djyakov', Doctor of Technical Science, Docent, Yu.V Litovka', Doctor of Technical Science, Professor,

(ORCID: 0000-0002-5792-340X)

DOI: 10.22184/1993-8578.2019.12.3-4.212.219

Получено: 4.12.2018г.

В работе приведены результаты исследования влияния углеродных нанотрубок торговой марки "Таунит" на коррозионные характеристики гальванического покрытия сплавом олово-висмут (Sn-Bi) в растворе $0,1 \mathrm{M} \mathrm{Na}_{2} \mathrm{SO}_{4}$. Показано, что добавки снижают потенциал коррозии до $54 \%$.

The article presents research results of the effect of carbon nanotubes (trade mark "Taunit") on corrosion characteristics of electroplating coating with a tin-bismuth alloy $(\mathrm{Sn}-\mathrm{Bi})$ in $0,1 \mathrm{~mol}$ $\mathrm{Na}_{2} \mathrm{SO}_{4}$ solution. It was shown that additives reduce the corrosion potential up to $54 \%$.

\section{ВВЕДЕНИЕ}

Оловянное покрытие на меди является анодным (или протекторным), поскольку стандартный электрохимический потенциал олова меньше, чем у меди. Это означает, что в коррозионно-активной среде, в первую очередь, разрушается олово, и только после полного растворения олова на определенном участке будет повреждаться медь. Олово является достаточно стойким к коррозии металлом, поэтому применение оловянного покрытия значительно увеличивает срок службы гальванизирован ${ }^{-}$ ных медных изделий. Для увеличения коррозионной стойкости Sn-покрытия осаждаются из электролитов с блескообразователями и легируются висмутом (т.е. осаждается сплав "олово-висмут").

Как известно, для защиты от коррозии также широко используются ингибиторы - вещества, снижающие скорость, по крайней мере, одного из процессов, протекающих на поверхности металла. Малые добавки ингибитора изменяют структуру покрытия, повышая тем самым механические и антикоррозионные свойства сплава [1]. В качестве ингибитора коррозии в последнее время активно применяются наноуглеродные материалы. Хорошие результаты при использовании углеродных нанотрубок (УНТ) получены для цинкового [2-5] и никелевого 
[6-10] покрытий. Используемый в работе наноуглеродный материал, зарегистрированный под торговой маркой "Таунит", представляет собой фуллереноподобные углеродные нанотрубки - длинные полые волокна, состоящие из графеновых слоев (в количестве не более 30), диаметром 10...60 нм и длиной 1-2 мкм. При этом количество структурированного углерода в них - не менее 95\% [11]. "Таунит" производится в ООО "НаноТехЦентр" (г. Тамбов).

Целью работы являлось исследование влияния ингибирующей добавки УНТ "Таунит" в составе электролита для создания оловянных покрытий на коррозионную стойкость покрытия "олово-висмут".

\section{МЕТОДИКА ЭКСПЕРИМЕНТА И РЕЗУЛЬТАТЫ}

Проводилась серия экспериментов получения гальванического покрытия сплавом SnBi из электролита следующего состава: сульфат олова $\mathrm{SnSO}_{4}$ (ТУ 6-09-1502-72) - 35 г/л; сульфат висмута $\mathrm{Bi}_{2}\left(\mathrm{SO}_{4}\right)_{3}-1,5$ г/л; серная кислота $\mathrm{H}_{2} \mathrm{SO}_{4}$ (ГОСТ 667-77) - 180 г/л; формалин 40\% $\mathrm{CH}_{2} \mathrm{O}$ (ГОСТ 1625-75) - 6 мл/л; блескообразующая добавка "Экомет -Л6" - 45 мл/л.

Процесс нанесения сплава $\mathrm{Sn}-\mathrm{Bi}$ проводили в стационарных электролитических ячейках. Покрываемые образцы - медные детали (сплав M3) площадью $28 \mathrm{~m}^{2}$ размещались на подвесках. Перемешивание электролита осуществляли с использованием качающихся штанг. Аноды изготавливали из олова и помещали в чехлы из полипропиленовой ткани.
Режим осаждения: катодная плотность тока 1-3 А/дм ${ }^{2}$; температура электролита $18-25^{\circ} \mathrm{C}$. В отсутствие тока аноды извлекались из ванны.

После приготовления электролита в него вводили углеродные нанотрубки "Таунит" в виде порошка. Отдельные нанотрубки склонны к образованию агломератов. Решалась задача разделения агломератов на отдельные нанотрубки и равномерного их распределения в объеме электролита. Обе задачи решали методом ультразвуковой обработки электролита. Задача последующего деагломерирования решалась использованием в электролите поверхностно-активного вещества (ПАВ).

Для равномерного распределения и уменьшения агломератов наноматериала использовался ультразвуковой диспергатор Ил 100-6/4 с частотой 22 кГц и интенсивностью звука 786 Вт/см ${ }^{2}$. Диспергирование производили в течение 5 мин.

Для проведения сравнительного анализа покрытия $\mathrm{Sn}-\mathrm{Bi}$ наносили из электролитов без добавления нанотрубок и с добавками УНТ "Таунит" в диапазоне концентраций от 50 до 1600 мг/л.

При проведении процесса углеродные нанотрубки, движимые кинетической энергией катионов $\mathrm{Sn}^{2+}$, встраиваются в металлическую матрицу в ходе восстановительной катодной реакции $\mathrm{Sn}^{2+}+2 \mathrm{e} \rightarrow \mathrm{Sn}$. Концентрация нанотрубок в электролите снижалась в ходе эксплуатации. Поддержание концентрации УНТ "Таунит" в заданном диапазоне была одной из важнейших операций для процесса нанесения наномодифицированного покрытия. В работе [12]

\section{INTRODUCTION}

Tin coating on copper is anodic (or protective), as the standard electro-chemical potential of tin is lower than of copper. It means that in the corrosion-active medium first of all tin is destructed and only after the complete dissolution of tin in a certain location copper will be damaged. Tin is sufficiently resistant to corrosion metal, that is why application of a tin coating significantly increases the term of use of the electroplated copper produce. For the increase of corrosion resistance Sn-coatings are deposited from electrolytes with brighteners and doped with bismuth (i.e. tin-bismuth alloy is deposited).

As it is known, inhibitors - substances which decrease the speed of at least one of the processes occurring on the surface of a metal are widely used for the protection from corrosion. Small additions of an inhibitor modify the structure of the coating augmenting in this way mechanical and corrosion-resistant properties of the alloy [1]. Currently carbon nanomaterials have been actively employed as inhibitors of corrosion. Good results for zink [2-3] and nickel [6-1] coating have been obtained using carbon nanotubes (CNT). The used during the process nanomaterial, registered under the trademark "Taunit", constitutes fullerene-like carbon nanotubes - long hollow fibers consisting of graphene layers (in the quantity not more than 30), diameters from 10 to $60 \mathrm{~nm}$ and $1-2 \mu \mathrm{m}$ in length. Considering the amount of structurized carbon in them not less than 95\% [11]. "Taunit" is produced at LLC "NanoTechCentre", Tambov.

The aim of the work was the study of the influence of the inhibiting additive of CNT "Taunit" in the composition of the electrolyte for the creation of tin coatings on corrosion resistance of the coating "tin-bismuth". 
изложен разработанный авторами оптический метод измерения концентрации УНТ "Таунит" в электролитах, основанный на поглощении, рассеивании и отражении светового потока поликристаллическим графитом, а его реализация основывается на измерении оптической плотности и коэффициента пропускания жидкостных растворов, а также на определении концентрации вещества по предварительно полученной эмпирической модели.

\section{ИССЛЕДОВАНИЕ ОПТИЧЕСКОЙ ПЛОТНОСТИ ЭЛЕКТРОЛИТА}

Оценку значений оптической плотности производили согласно ГОСТ 15150-69 фотоэлектрическим фотометром "КФК-3" [13].

Использовали различные пробы электролитов, как свежеприготовленных, так и находившихся в пробирках в течение месяца после приготовления и эксплуатации, и дистиллированную воду в качестве эталонного образца. Чистый, не бывший в эксплуатации электролит, необходим для построения функции оптической плотности и определения рабочей длины волны. Бывший в эксплуатации электролит необходим для определения погрешности измерений, связанных с загрязнением электролита оксидами, шламами деталей, осадками из-за кристаллизации компонентов электролита. Эксплуатируемые электролиты с различными концентрациями УНТ "Таунит" необходимы для определения концентрации УНТ как функции от оптической плотности.

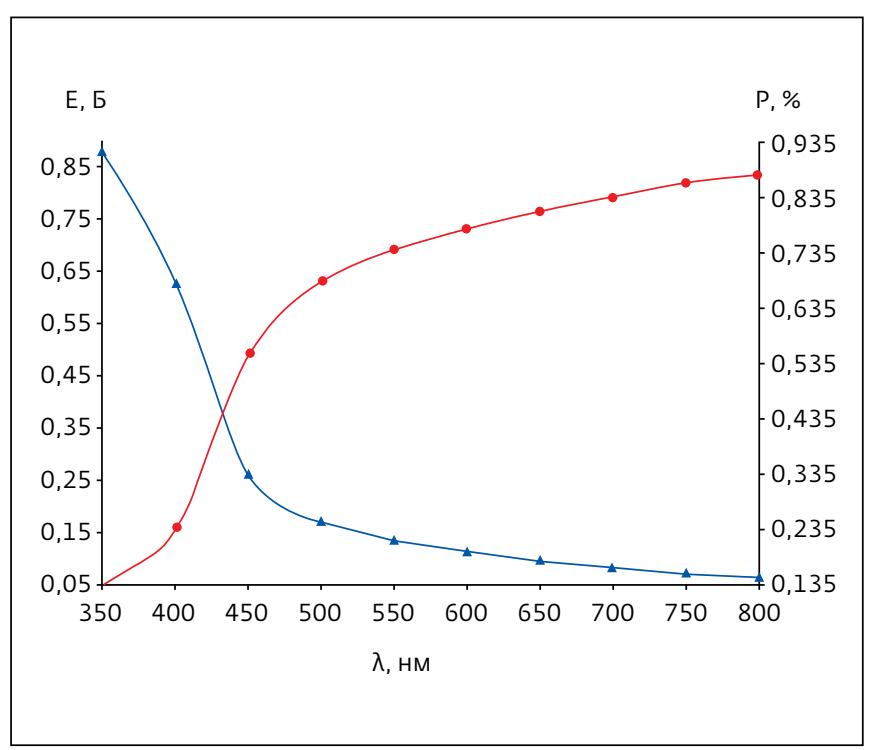

Puc.1. Зависимости оптической плотности (А) и коэффициента пропускания чистого электролита Sn-Bi (•) от диины волны

Fig.1. Dependences optical density ( $\mathbf{\Delta})$ and the coefficient of pure electrolyte Sn-Bi transmittance (•) on the length of the wave

Были измерены оптические плотности чистого электролита в диапазоне длин волн поглощения излучения от 350 до 800 нм с шагом 50 нм при температуре раствора $20^{\circ} \mathrm{C}$. По полученным данным построен график зависимости оптической плотности электролита от длины волны излучения (рис.1).

Для определения рабочей длины волны необходимо было найти участок кривой, где

\section{METHODS OF THE EXPERIMENT AND RESULTS}

There was a series of experiments for producing of electroplating coating with a $\mathrm{Sn}-\mathrm{Bi}$ alloy from the electrolyte consisting of the following: stannic sulfate $\mathrm{SnSO}_{4}$ (Tech. stand. 6-09-1502-72) - $35 \mathrm{~g} / \mathrm{l}$; bismuth sulfate $\mathrm{Bi}_{2}\left(\mathrm{SO}_{4}\right)_{3}-1,5 \mathrm{~g} / \mathrm{l}$; sulfuric acid $\mathrm{H}_{2} \mathrm{SO}_{4}$ (State Stand. 667-77) - $180 \mathrm{~g} / \mathrm{l}$; formalin $40 \% \mathrm{CH}_{2} \mathrm{O}$ (State Stand. 1625-75) - $6 \mathrm{ml} / \mathrm{l}$; the additive brightener "Ecomet - L6" - $45 \mathrm{ml} / \mathrm{l}$.

The process of application of the Sn-Bi alloy was conducted in the static electrolytic cells. The samples being coated - copper parts (the alloy M3) with surface area $22 \mathrm{~mm}^{2}$ were placed on the plating rack. Mixing of the electrolyte was performed using walking beams. Anodes were made of tin and placed in the polypropylene fabric cases.

The mode of deposition: the cathode current density was $1-3 \mathrm{~A} / \mathrm{dm}^{2}$; the temperature of the electrolyte $18-25^{\circ} \mathrm{C}$. In the absence of the current anodes were withdrawn from the bath.

After preparing of the electrolyte, carbon nanotubes "Taunit" were introduced in the form of powder. Individual nanotubes tend to form agglomerates. The tasks of breaking up the agglomerates into separate nanotubes and even distribution of them in the electrolyte volume were being addressed. Both tasks were being solved by the method of ultrasonic treatment of the electrolyte. The problem of the following deagglomeration was being dealt with by adding into the electrolyte of a surface active agent (SAA).

For the even distribution and minimization of agglomerates of the nanomaterial the ultrasonic disperser IL 100-6/4 with the frequency of $22 \mathrm{kHz}$ and the sound intensity of $786 \mathrm{~W} / \mathrm{cm}^{2}$ was being used. Dispersion was being performed for five minutes. 


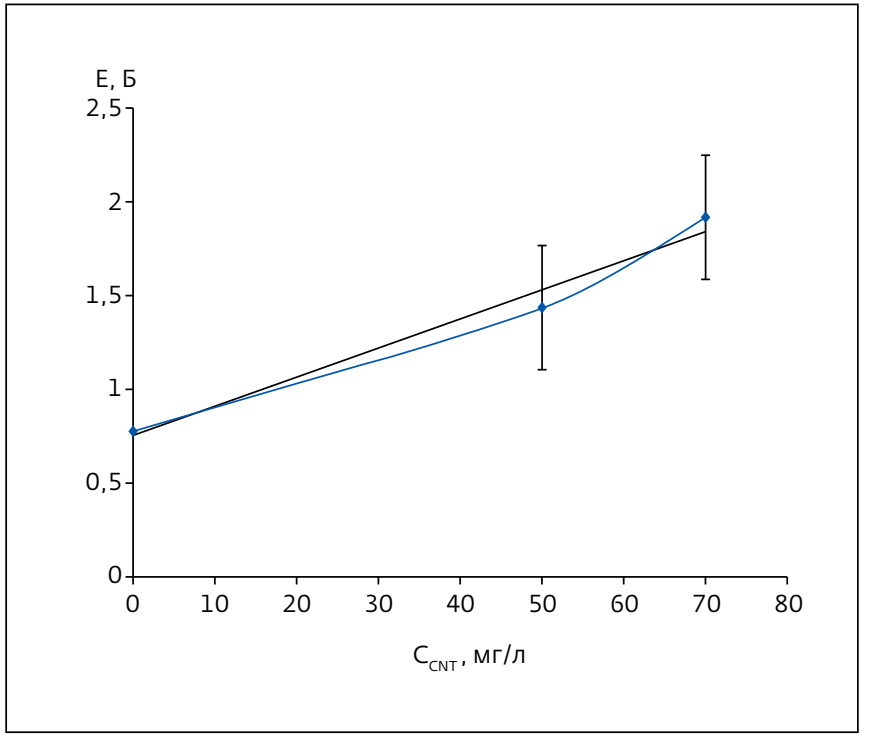

Pис.2. Зависимость оптической плотности электролита Sn-Bi om концентрации УНТ в диапазоне от 0 до 70 мг/л Fig.2. Dependence of the optical density of the electrolyte $\mathrm{Sn}-\mathrm{Bi}$ against the concentration of the CNT in the range from 0 to $70 \mathrm{mg} / \mathrm{l}$

выполнилось хотя бы одно из условий: оптическая плотность (Е) имеет максимальную величину; ход кривой параллелен горизонтальной оси, то есть оптическая плотность слабо зависит от длины волны $\lambda[14]$.

Из графика следует, что для исследованного диапазона $\lambda$ максимальное значение оптической плотности наблюдается при $\lambda=350$ нм. После определения рабочей длины волны были проведены многократные измерения для различных проб электролитов. Измеряли оптическую плотность Е и коэффициент пропускания Р при изменении концентрации $\left(\mathrm{C}_{\mathrm{CNT}}\right)$ наноуглерода "Таунит" в электролитах.

По выборке устойчивых значений был построен график (рис.2). По полученным данным была найдена зависимость оптической плотности от концентрации УНТ $\left(\mathrm{C}_{\mathrm{CNT}}\right)$, имеющая наибольшую величину достоверности аппроксимации $\left(\mathrm{R}^{2}\right)$.

Так как наилучшие значения антикоррозионной стойкости для других покрытий [2] были получены при наименьших концентрациях УНТ "Таунит", то для удобства использования зависимость оптической плотности электролита от концентрации УНТ можно привести в диапазоне от 0 до $70 \mathrm{мг/л.}$

Для удобства работы табличные данные были аппроксимированы выражением:

$$
\mathrm{CCNT}=63,7 \mathrm{E}-47,44
$$

при $\mathrm{R}^{2}=0,9763$.

Для коррекции концентрации УНТ отбирали пробу электролита и измеряли значение оптической плотности Е прибором КФК-3. Далее по аппроксимирующему выражению (1) вычисляли значение $\mathrm{C}_{\mathrm{CNT}}$. Если концентрация нанотрубок становилась меньше заданного порогового значения, в электролит добавляли требуемое количество углеродного наноматериала [15].
For carrying out of the comparative analysis Sn-Bi coatings were deposited from electrolytes without adding nanotubes and with the CNT "Taunit" additives the diversity of concentrations being between 50 and $1600 \mathrm{mg} / \mathrm{l}$.

During the process of electrodeposition carbon nanotubes driven by the kinetic energy of $\mathrm{Sn}^{2+}$ cations, fit in the metallic matrix in the course of the reductive cathode reaction $\mathrm{Sn}^{2+}+2 \mathrm{e} \rightarrow$ $\mathrm{Sn}$. Concentration of nanotubes in the electrolyte lowered during the exploitation. Maintenance of the CNT "Taunit" concentration within the set limits was one of the most important procedures for the process of the nanomodified coating application. In the study [12] the optical method of measurement of the CNT "Taunit" concentration in electrolytes, based on absorption, diffusion and reflection of the luminous flux by polycrystalline graphite is disclosed by the authors, and its realization is grounded on the measurement of the optical density and liquid solutions transmittance ratio and also on the measurement of the substance concentration according to the previously obtained empirical model.

\section{THE STUDY OF THE OPTICAL DENSITY OF THE ELECTROLYTE}

The assessment of measurements of the optical density was performed according to the State Standards (GOST) 15150-69 by the photoelectric photometer "KFK-3" [13].

Various samples of electrolytes were used, both freshly prepared and having been in the test-tubes for a month after preparation and use, and also the distilled water as the reference sample. A pure, unused electrolyte is necessary for the construction of the function of the optical density and determining the wave operating length. 


\section{ИССЛЕДОВАНИЕ КОРРОЗИОННОГО ПОВЕДЕНИЯ СПЛАВА}

Исследование коррозионного поведения сплава $\mathrm{Sn}$-Вi роводили в растворе $0,1 \mathrm{M} \mathrm{Na}_{2} \mathrm{SO}_{4}$ на приборе "Электрохимическая рабочая станция Zive SP2" (WonaTech, Южная Корея) со скоростью развертки $1 \mathrm{MB} / \mathrm{c}$.

\section{РЕЗУЛЬТАТЫ И ИХ ОБСУЖДЕНИЕ}

В табл.1 представлены результаты исследования временной зависимости потенциала свободной коррозии сплава Sn-Bi с добавкой УНМ "Таунит" в растворе $0,1 \mathrm{M} \mathrm{Na}_{2} \mathrm{SO}_{4}$, которые фиксировали в течение 300 с. Исследования показали, что добавки УНТ "Таунит" в пределах 50-1600 мг/л

Таблица 1. зависимость потенциала коррозии меди $\varphi$, покрытой сплавом Sn-Bi, от времени и концентрации УнМ "Таунит" в растворе $0,1 \mathrm{M} \mathrm{Na}_{2} \mathrm{SO}_{4}$

Table 7. Dependence of the copper corrosion potential $\varphi$, covered by the alloy Sn-Bi on the time and concentration of the CNT "Taunit" in the solution $0,7 \mathrm{~mol} \mathrm{Na}_{2} \mathrm{SO}_{4}$

\begin{tabular}{|c|c|c|c|c|c|c|c|}
\hline \multirow{3}{*}{$\begin{array}{c}\text { Время } \\
\text { Выдержки, с }\end{array}$} & \multicolumn{7}{|c|}{ Содержание УНМ, мг/л } \\
\hline & $\mathbf{0}$ & 50 & 70 & 100 & 500 & 1000 & 1600 \\
\hline & $\Phi, \mathrm{B}$ & $\Phi, \mathrm{B}$ & $\Phi, \mathrm{B}$ & $\Phi, B$ & $\Phi, \mathrm{B}$ & $\Phi, B$ & $\Phi, \mathrm{B}$ \\
\hline $0-20$ & $-0,426$ & $-0,271$ & $-0,304$ & $-0,287$ & $-0,261$ & $-0,257$ & $-0,183$ \\
\hline $21-40$ & $-0,417$ & $-0,265$ & $-0,302$ & $-0,281$ & $-0,257$ & $-0,251$ & $-0,182$ \\
\hline $41-60$ & $-0,413$ & $-0,257$ & $-0,299$ & $-0,273$ & $-0,255$ & $-0,247$ & $-0,180$ \\
\hline $61-80$ & $-0,409$ & $-0,249$ & $-0,297$ & $-0,266$ & $-0,253$ & $-0,245$ & $-0,179$ \\
\hline $81-100$ & $-0,405$ & $-0,231$ & $-0,295$ & $-0,26$ & $-0,249$ & $-0,243$ & $-0,177$ \\
\hline $101-120$ & $-0,399$ & $-0,222$ & $-0,292$ & $-0,254$ & $-0,249$ & $-0,242$ & $-0,177$ \\
\hline $121-140$ & $-0,399$ & $-0,211$ & $-0,289$ & $-0,259$ & $-0,247$ & $-0,241$ & $-0,176$ \\
\hline $141-160$ & $-0,398$ & $-0,205$ & $-0,287$ & $-0,256$ & $-0,245$ & $-0,239$ & $-0,175$ \\
\hline $161-180$ & $-0,398$ & 0,201 & $-0,287$ & $-0,252$ & $-0,243$ & $-0,239$ & $-0,174$ \\
\hline 181-200 & $-0,396$ & $-0,198$ & $-0,284$ & $-0,246$ & $-0,241$ & $-0,238$ & $-0,173$ \\
\hline $201-220$ & $-0,395$ & $-0,18$ & $-0,283$ & $-0,242$ & $-0,239$ & $-0,238$ & $-0,173$ \\
\hline $221-240$ & $-0,391$ & $-0,173$ & $-0,282$ & $-0,241$ & $-0,239$ & $-0,237$ & $-0,171$ \\
\hline $241-260$ & $-0,389$ & $-0,164$ & $-0,28$ & $-0,238$ & $-0,238$ & $-0,237$ & $-0,169$ \\
\hline $261-280$ & $-0,389$ & $-0,153$ & $-0,274$ & $-0,235$ & $-0,237$ & $-0,235$ & $-0,165$ \\
\hline $281-300$ & $-0,387$ & $-0,141$ & $-0,271$ & $-0,220$ & $-0,235$ & $-0,234$ & $-0,163$ \\
\hline
\end{tabular}


способствуют смещению потенциала $\phi(B)$ коррозии в положительную область (см. табл.1), что характеризует динамику формирования защитной оксидной пленки.

Анализ поляризационных кривых (рис.3) показал, что плотность тока коррозии і покрытия $\mathrm{Sn}-\mathrm{Bi}$, полученного в присутствии $50 \mathrm{mг/л}$ Унт "Таунит" по сравнению с аналогичным покрытием, полученным без добавления нанотрубок, снижается на $99 \%$.

Скорость коррозии оценивали по точке пересечения катодной и анодной поляризационных кривых. Видно, что точка пересечения кривых соответствует меньшему току коррозии I. Природу торможения катодной реакции объяснить трудно, но в первом приближении она обусловлена изменением структуры покрытия.

В табл.2 приведены коррозионно-электрохимические характеристики сплава Sn-Bi с добавкой УНТ "Таунит" в растворе $\mathrm{Na}_{2} \mathrm{SO}_{4} \mathrm{C}_{\text {концен- }}$ трацией 0,1 M. Добавки УНТ "Таунит" улучшают потенциал коррозии исходного сплава на 28-54\%. Наилучший результат наблюдали при добавке УНТ "Таунит" 50 мг/л.

\section{выводы}

Обнаружено, что углеродные нанотрубки "Таунит" в составе электролита осаждения сплава "олово-висмут" на медь проявляют ингибирующее действие, тем самым расширяют область пассивного состояния меди, что

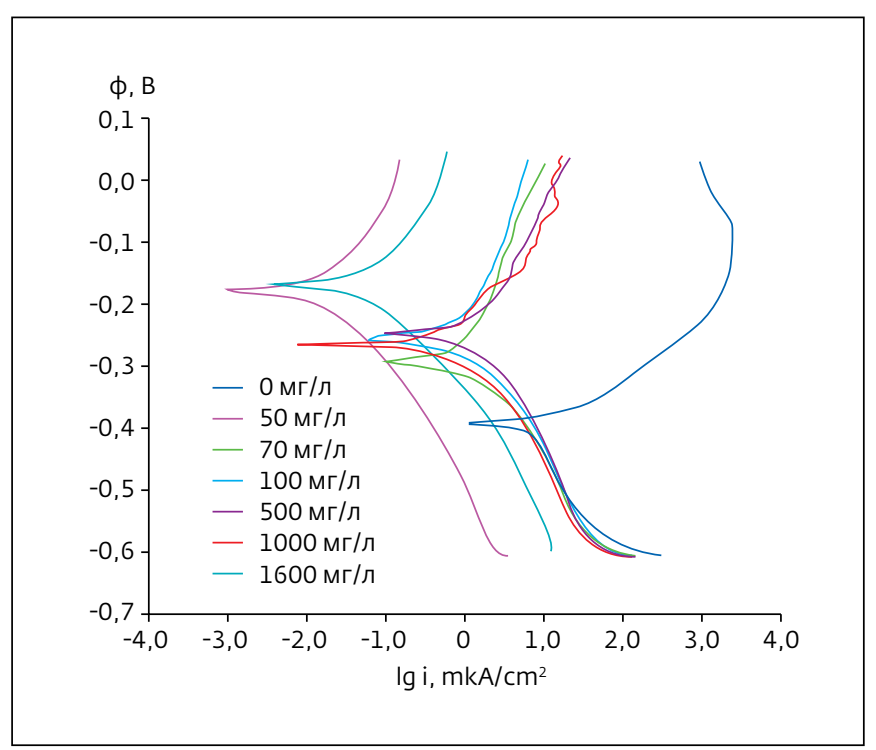

Puc.3. Вольт-амперные зависимости покрытия Sn-Bi в популогарифмических координатах (концентрация раствора $\left.\mathrm{Na}_{2} \mathrm{SO}_{4}-0,1 \mathrm{M}\right)$

Fig.3. Volt-ampere dependences of the Sn-Bi coating in semilogarithmic coordinates (concentration of the solution $\left.\mathrm{Na}_{2} \mathrm{SO}_{4}-0,1 \mathrm{~mol}\right)$

приводит к увеличению противокоррозионного действия покрытий.

Полученные результаты показали, что ток коррозии в присутствии УНТ по сравнению с покрытием, полученным без добавления УНТ, снижается максимально на 99\%, а потенциал
The used electrolyte is necessary for determining the accuracy of measurements, connected with the pollution of the electrolyte by oxides, silts of the parts, residual because of the electrolyte components crystallization. The electrolytes being used with different concentrations of the CNT "Taunit" are required for determining concentration of the CNT as the function of the optical density.

The optical densities of the pure electrolyte were within the range of the length of the emission absorption waves from 350 till $800 \mathrm{~nm}$ with the spacing of $50 \mathrm{~nm}$ at the solution temperature of $20^{\circ} \mathrm{C}$. After the obtained data the graph of the electrolyte optical density against the length of the emission wave was drawn (see Fig.1).

For determining the operational length of the wave it was necessary to find the segment of the curve, where at least one of the conditions would be true: optical density (E) has the maximum value; the curve is parallel to the horizontal axis, i.e. optical density is loosely dependant on the wave length $\lambda$ [14].

The graph shows that for the studied range $\lambda$ maximum value of the optical density is observed at $\lambda=350 \mathrm{~nm}$. After determining the operating length of the wave multiple measurements for different samples of electrolytes were carried out.

The optical density E and transmittance coefficient $\mathrm{P}$ at the change of concentration $\left(\mathrm{C}_{\mathrm{CNT}}\right)$ of the nanocarbon "Taunit" in electrolytes was measured.

After the selection of stable values the graph was constructed (see Fig.2). According to the obtained data the dependence of the optical density on the concentration of $\mathrm{CCN}\left(\mathrm{C}_{\mathrm{CNT}}\right)$, having the greatest value of the accuracy approximation $\left(\mathrm{R}^{2}\right)$. 


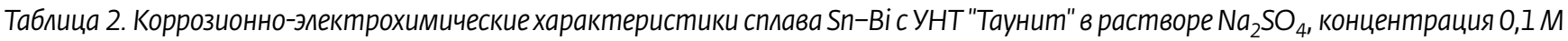
Table 2. The corrosive - electrochemical properties of the $\mathrm{Sn}$-Bi alloy with the additive of the CNT "Taunit" in the solution of $\mathrm{Na}_{2} \mathrm{SO}_{4} \mathrm{with}^{-}$ 0,1 mol concentration

\begin{tabular}{|c|c|c|c|c|c|c|c|}
\hline Концентр, г/л & $\mathbf{0}$ & 50 & 70 & 100 & 500 & 1000 & 1600 \\
\hline$\phi, B$ & $-0,401$ & $-0,181$ & $-0,288$ & $-0,254$ & $-0,246$ & $-0,242$ & $-0,184$ \\
\hline I, A & $2,00 E-06$ & 4,00E-09 & 2,70E-07 & 2,00E-07 & $2,92 E-07$ & 1,10E-07 & 1,70E-08 \\
\hline $\mathrm{i}, \mathrm{MKA} / \mathrm{CM}^{2}$ & 7,07 & 0,01 & 0,95 & 0,71 & 1,03 & 0,39 & 0,06 \\
\hline
\end{tabular}

коррозии смещается в положительную область. При концентрации в электролите УНТ "Таунит" 50 мг/л достигаются максимальные показатели коррозионной стойкости.

\section{ЛИТЕРАТУРА}

1. Choi E.K., Lee K.Y., Oh T.S. Fabrication of multiwalled carbon nanotubes-reinforced Sn nanocomposites for lead-free solder by an electrodeposition process // Journal of Physics and Chemistry of Solids. 2008. V. 69. P. 1403-1406.

2. Дьяков И.А., Симагин Д.Н. , Литовка Ю.В. , Дьяков И.А. Процесс нанесения цинковых покрытий из электролитов с добавками наноуглерода для повышения защитной способности от коррозии // Нанотехника. 2014. № 3(39). С. 20-23.
3. Симагин Д.Н. Метод нанесения наномодифицированных цинковых гальванических покрытий для защиты металлов от коррозии // Наноматериалы и нанотехнологии: Проблемы и перспективы: II Международная заочная научная конференция, Саратов: электронное научное издание. - ФГУП НТЦ "Информрегистр", Депозитарий электронных изданий, 2013. С. 147-150.

4. Литовка Ю.В., Симагин Д.Н., Ткачев А.Г., Дьяков И.А. Использование наноматериалов в электрохимических покрытиях // I Международной научной конференции "Графен и родственные структуры: синтез, производство и применение", г. Тамбов. 2015. С. 206-207.
As the best values for the corrosion resistance for other coatings [2] were obtained at the lowest concentrations of CNT "Taunit", then for the convenience of use, dependence of the optical density of the electrolyte on the concentration of the CNT is given in the range from 0 to $70 \mathrm{mg} / \mathrm{l}$.

For the convenience of work the table data were approximated by the equation:

$$
\mathrm{CCNT}=63,7 \mathrm{E}-47,44
$$

when $\mathrm{R}^{2}=0,9763$.

For the correction of the concentration of the CNT the sample of the electrolyte was taken and the value of optical density $\mathrm{E}$ was measured by the photometer KFK-3. Then after the approximating equation (1) the value $\mathrm{C}_{\mathrm{CNT}}$ was calculated. If the concentration of nanotubes became lower than the determined threshold value the required quantity of the nanomaterial was added [15].

\section{THE STUDY OF THE CORROSION BEHAVIOR OF THE ALLOY}

The study of the corrosion behavior of the alloy $\mathrm{Sn}-\mathrm{Bi}$, was conducted in the solution $0,1 \mathrm{~mol} \mathrm{Na}_{2} \mathrm{SO}_{4}$ on the apparatus "Electrochemical workstation Zive SP2" (WonaTech, South Korea) at the speed of the time base $1 \mathrm{mV} / \mathrm{s}$.

\section{RESULTS AND THEIR DISCUSSION}

Table 1 shows the results of the study of the time dependence of the potential of the free corrosion of the alloy $\mathrm{Sn}$-Bi with the additive CNT "Taunit" in the solution of $0,1 \mathrm{Mol} \mathrm{Na}_{2} \mathrm{SO}_{4}$, which were being registered for 300 seconds.

The studies revealed that the additive CNT "Taunit" within the range of 50-1600 $\mathrm{mg} / \mathrm{l}$ contributes to the shift of potential $\phi(V)$ of corrosion into the positive area (table 1), which characterizes the dynamics of the protective oxide film formation.

The analysis of the polarization curves (see Fig.3) showed, 
5. Симагин Д.Н., Литовка Ю.В. Процесс получения наномодифицированных цинковых покрытий с повышенной равномерностью // Вестник Тамбовского государственного технического университета. 2013. № 4. C. 886-889.

6. Jeon Y.S., Byun J.Y., Oh T.S. Electrodeposition and mechanical properties of Ni-carbon nanotube nanocomposite coatings // J. Phys. Chem. Sol. 2008. V. 69. P. 1391-1394.

7. Arai S., Fujimori A., Murai M., Endo M. Excellent solid lubrication of electrodeposited nickelmultiwalled carbon nanotube composite films // Materials Letters. 2008. V. 62. P. 3545-3548.

8. Chen X.H., Chen C.S., Xiao H.N., Cheng F.Q., Zhang G., Yi G.J. Corrosion behavior of carbon nanotubes-Ni composite coating // Surface \& Coatings Technology. 2005. V. 191. P. 351-356.

9. Shi L., Sun C.F., Gao P., Zhou F., Liu W.M. Electrodeposition and characterization of $\mathrm{Ni}-\mathrm{Co}$-carbon nanotubes composite coatings // Surface \& Coatings Technology. 2006. V. 200. P. 4870-4875.

10. Guo Ch., Zuo Y., Zhao X., Zhao J., Xiong J. The effects of pulse-reverse parameters on the properties of $\mathrm{Ni}^{-}$-carbon nanotubes composite coatings // Surface \& Coatings Technology. 2007. V. 201. P. 9491-9496.

11. Мищенко С.В., Ткачев А.Г. Углеродные наноматериалы. Производство, свойство, применения. - М.: Машиностроение, 2008. 320 c.
12. Давыдова Д.В., Дьяков И.А., Давыдова Д.В., Мухин Р.Ю. К вопросу математического моделирования оптических свойств электролитов лужения // Вестник Тамбовского государственного технического университета. 2014. Т. 20. 2. С. 329-335.

13. Фотометры фотоэлектрические КФК-3. Руководство по эксплуатации [Электронный ресурс] - Режим доступа: http: // www.medtexnika.com/catalog/img/kfk-3_instruction. pdf

14. Пат. 2482227. Российская Федерация, МПК C25D21/14, G05D11/00. Способ корректировки наномодифицированного электролита / Литовка Ю.В.; Дьяков И.А.; Кузнецова О.А.; Ткачев А.Г.; заявитель и патентообладатель общество с ограниченной ответственностью "Наногальваника" (ООО "Наногальваника"). № 2011130577/02.

15. Давыдова Д.В., Дьяков И.А. К вопросу регулирования концентрации углеродных нанотрубок в электролитах // Некоторые вопросы анализа, алгебры, геометрии и математического образования: материалы молодежной международной научной конференции "Методы современного математического анализа и геометрии и их приложения" / Воронежский государственный педагогический университет, кафедра высшей математики, - Воронеж: Издательско-полиграфический центр "Научная книга". 2016. Вып. 5, Ч. І. С. 121-122. that the density of the corrosion current $\mathrm{i}$ of the Sn-Bi coating, obtained in the presence of $50 \mathrm{mg} / \mathrm{l}$ of the CNT "Taunit", in comparison with the analogous coating received without the addition of the nanotubes decreases by $99 \%$.

The rate of corrosion was assessed by the intersection point of the anode and cathode polarization curves. It is seen that the intersection of the curves corresponds to the lesser corrosion current I. The reason of the cathode inhibition reaction is difficult to account for, but according to the initial estimate it is determined by the change of the coating structure.

Table 2 gives the corrosive - electrochemical properties of the Sn-Bi alloy with the additive of the CNT "Taunit" in the solution of $\mathrm{Na}_{2} \mathrm{SO}_{4}$ with $0,1 \mathrm{~mol}$ concentration. The additives of the CNT "Taunit" improve the corrosion potential of the original alloy by $28-54 \%$. The best result was observed at the introduction of $50 \mathrm{mg} / \mathrm{l}$ of the CNT "Taunit" additive.

\section{CONCLUSIONS}

It was registered that carbon nanotubes "Taunit" in the content of the "tin-bismuth" deposition alloy electrolyte on copper demonstrate the inhibiting effect, thus expanding the area of the passive state of copper, which leads to increase in the corrosion resistance effect of the coatings.

The obtained results revealed that the corrosion current in the presence of CNT in comparison with the coating obtained without the CNT additive drops by $99 \%$, and the potential of the corrosion shifts into the positive area. At the concentration of $50 \mathrm{mg} / \mathrm{l}$ of the CNT "Taunit" in the electrolyte maximum values of corrosion resistance are achieved. 